\title{
Taxonomy, morphology and distribution of Cymatosiraceae (Bacillariophyceae) in the littorals of Santa Catarina and Rio Grande do Sul
}

\author{
Marinês Garcia ${ }^{1,2}$ \\ ${ }^{1}$ Universidade Federal de Pelotas, Rio Grande do Sul, RS, Brazil. \\ ${ }^{2}$ Corresponding author: Marinês Garcia, e-mail: marines@ufpel.edu.br
}

GARCIA, M. Taxonomy, morphology and distribution of Cymatosiraceae (Bacillariophyceae) in the littorals of Santa Catarina and Rio Grande do Sul. Biota Neotropica. 16(2): e20150139. http://dx.doi.org/ 10.1590/1676-0611-BN-2015-0139

\begin{abstract}
Species of Cymatosiraceae (diatoms) studied from Santa Catarina and Rio Grande do Sul littorals: Campylosira cymbelliformis, Cymatosira belgica, Cymatosirella minutissima, Plagiogrammopsis minima and Plagiogrammopsis vanheurckii) are presented with a morphological description, dimension data, distribution in the studied area and are illustrated in light microscope, and scanning and transmission electron microscopes. Superficial sand samples from the swash zone and plankton were collected from over 30 marine sandy beaches. Cymatosirella minutissima and Plagiogrammopsis minima are new recordings in Brazil widening their distribution to South America, previously being restricted to Europe. Campylosira cymbelliformis was the species most often observed in plankton samples and Plagiogrammopsis minima in sediment samples. Cymatosira belgica and Plagiogrammopsis minima were recorded as abundant species in Mariscal, Quatro Ilhas and Zimbros reaching a relative frequency of 9.6\%. The study adds new morphological data to some taxa as the presence of rimoportula on C. minutissima and one row of poroids on copulae of $P$. minima, these features being in agreement with Cymatosiraceae diagnosis.
\end{abstract}

Keywords: biodiversity, psammic diatoms, sandy beaches, South Atlantic Ocean.

GARCIA, M. Taxonomia, morfologia e distribuição de Cymatosiraceae (Bacillariophyceae) nos litorais de Santa Catarina e Rio Grande do Sul. Biota Neotropica. 16(2): e20150139. http://dx.doi.org/10.1590/ 1676-0611-BN-2015-0139

Resumo: As espécies de Cymatosiraceae (diatomácea) encontradas no litoral de Santa Catarina e Rio Grande do Sul: Cymatosira belgica, Campylosira cymbelliformis, Cymatosirella minutissima, Plagiogrammopsis minima e Plagiogrammopsis vanheurckii são apresentadas com descrições morfológicas acompanhadas de dados referentes a dimensões, distribuição na área de estudo e ilustrações em microscopia óptica, e eletrônica de varredura e de transmissão. As amostras da areia superficial foram coletadas na região de varrido das ondas e de plâncton em mais de 30 praias arenosas. Cymatosirella minutissima and Plagiogrammopsis minima são registros novos para o Brasil ampliando sua distribuição para a América do Sul antes restritas à Europe. Campylosira cymbelliformis foi a espécies mais frequentemente observada nas amostras de plâncton and Plagiogramma minima in the sediment samples. Cymatosira belgica e Plagiogrammopsis minima são registradas como espécies abundantes em Mariscal, Quatro Ilhas e Zimbros alcançando a freqüência relativa máxima de 9,6\%. Este estudo adiciona novos dados morfológicos para alguns táxons com a presença de uma rimopórtula em $C$. minutissima e uma fileira de poróides nas cópulas de P. minima, estando estas características de acordo com a diagnose da Cymatosiraceae.

Palavras-chave: Biodiversidade, diatomáceas psâmicas, Oceano Atlântico Sul, praias arenosas.

\section{Introduction}

The Cymatosiraceae family belongs to class Mediophyceae and according to Hasle et al. (1983) it presents eight genera mainly from the Northern Hemisphere: Cymatosira Grunow, Campylosira Grunow ex Van Heurck, Plagiogrammopsis Hasle, von Stosch \& Syvertsen, Brockmaniella Hasle, von Stosch \& Syvertsen, Minutocellus Hasle, von Stosch \& Syvertsen,
Leyanella Hasle, von Stosch \& Syvertsen, Arcocellulus Hasle, von Stosch \& Syvertsen and Papiliocellulus Hasle, von Stosch \& Syvertsen. Recently, Sabbe et al. (2010) e Dabek et al. (2013) described a new genus Cymatosirella Dabek, Witkowski \& Sabbe with a known distribution to Europe and South Africa and Pierrecomperia Sabbe, Vyverman \& Ribeiro which was confined to Europe until now. 
The most important features in this family are the bipolar symmetry, heterovalvy (present in several genera as in Campylosira and Cymatosira), open girdle bands in a number of 4 or more, areolae occluded by an external cribrum, the chains organizational pattern, presence of fascia on the centre of the valve face reaching the valve margin, one rimoportula per valve located on the central position, ocelluli (a type of small ocello), pseduoseptum and the simple or complex spines that are ultra-structural details useful for their correct identification.

In Brazil, the family is represented by Cymatosira atlantica Frenguelli, Cymatosira lorenziana Grunow, Cymatosira belgica Grunow, Campylosira cymbelliformis (A. Schimdt) Grunow ex Van Heurck and Plagiogramma vanheurcki Grunow which were registered by Procopiak et al. 2006 to Paraná State (Brazil).

Regarding its presence in the Rio Grande do Sul State littoral, there are three taxonomic studies reporting Cymatosiraceae: one carried out with plankton samples from Tramandaí beach by Rosa (1982), another executed with associated diatoms on Hypnea musciformis (Wulfen) Lamouroux from rocks of Torres beach by Busellato-Toniolli (1986) and a third studied conducted on exposed sand sediments of the sandy beach of Praia Azul by Garcia-Baptista (1993). All authors have found only Campylosira cymbelliformis and Garcia-Baptista (1993) records the species as frequent in sand samples (present in 105 of the 189 samples studied) with in average number varying from 500 to 3,100 frustules $/ \mathrm{cm}^{3}$ while other studies have no data on its abundance or frequency.

More recently, Garcia (2013) described Extubocellulus brasiliensis M.Garcia as a new species for Science with a known distribution to a few sandy beaches of Santa Catarina State.

Cymatosiraceae genera are widespread in benthic habitats and particularly common on sediments, but they can occur occasionally in plankton samples. Some species present a higher abundance in sandy sediments such as
Plagiogrammopsis minima (Salah) Sabbe \& Witkowski and Cymatosirella minutissima Sabbe et al. (2010) and others such as Cymatosira belgica are common in exposed mud samples of river deltas according to Manoylov \& Dominy (2013) and (Hassan et al. 2009), silty sediments and in plankton samples Muylaert \& Sabbe (1999). Hassan et al. (2009) showed their use for Paleosalinity reconstructions whereas $C$. belgica was related to marine or marine brackish environments in Argentina.

This paper aims at describing species of Cymatosiraceae showing the diversity of it from samples collected in Santa Catarina and Rio Grande do Sul State littorals with data on morphology, dimension, distribution in the studied area and illustrations in LM (Light Microscope), TEM (Transmission Electron Microscope) and SEM (Scanning Electron Microscope).

\section{Materials and Methods}

The first centimeter of sediment was scraped from exposed portions (next to the sea water and at a midway point between the dunes and the sea water) of sandy beaches located in Santa Catarina and Rio Grande do Sul State littorals (Table 1). Almost all beaches have a general arc shape and samples were collected at their extremities and at their middle totaling at least 6 samples per beach studied. Two set of samples were studied: the first set of samples (121) was collected in December 1995 and in January 1996, and the second set of samples (182) was collected from September 2001 to July 2002.

The sediment was collected by using a $3.7 \mathrm{~cm}$ diameter polyvinyl chloride tube, which was pressed down vertically into the sediment to a one centimeter depth. The sample was kept in flasks with $20 \mathrm{ml}$ of 3\% Lugol solution; later 4\% formaldehyde was added.

Plankton samples net (20 $\mu \mathrm{m}$ opening) were collected from Cassino beach (located in the Rio Grande do Sul littoral) on three dates: in March 2001, in October and in December 2005. These samples were fixed with formaldehyde $4 \%$.

Table 1. Presence of Cymatosiraceae species in the studied beaches (x) and relative frequency of species observed in abundance.

\begin{tabular}{|c|c|c|c|c|c|}
\hline Beaches & C. cymbelifformis & C. belgica & C. minima & P. minima & P. vanheurckii \\
\hline Araçá & - & $\mathrm{x}$ & $\mathrm{x}$ & - & - \\
\hline Bombas & - & - & - & $\mathrm{x}$ & - \\
\hline Canto Grande & - & - & - & - & - \\
\hline Cassino & $\mathrm{x}$ & $\mathrm{x}$ & - & - & - \\
\hline Gamboa & - & $\mathrm{x}$ & - & $\mathrm{x}$ & - \\
\hline Garopaba & - & - & - & $\mathrm{x}$ & - \\
\hline Guarda do Embaú & - & - & - & $\mathrm{x}$ & - \\
\hline Iró & $\mathrm{x}$ & - & - & - & - \\
\hline Itapirubá & $\mathrm{x}$ & - & - & - & - \\
\hline Mar Grosso & $\mathrm{x}$ & - & - & - & - \\
\hline Mariscal & - & $(3 \%)$ & $\mathrm{x}$ & - & - \\
\hline Navegantes & $\mathrm{x}$ & - & - & - & - \\
\hline Penha & - & - & - & $\mathrm{x}$ & - \\
\hline Perequê & $\mathrm{x}$ & $\mathrm{x}$ & - & - & - \\
\hline Quatro Ilhas & - & $\mathrm{x}$ & - & $(2-2.3 \%)$ & $\mathrm{x}$ \\
\hline São Miguel & - & - & - & $\mathrm{x}$ & - \\
\hline Siriú & - & - & - & $\mathrm{x}$ & - \\
\hline Tramandaí & $\mathrm{x}$ & - & - & - & - \\
\hline Zimbros & - & $\mathrm{x}$ & $\mathrm{x}$ & $(9.6 \%)$ & - \\
\hline
\end{tabular}


In order to separate diatoms from sediment, about $2 \mathrm{gr}$ of sediment and $2 \mathrm{~mL}$ from the fixative solution were taken from each flask, and to study plankton, a subsample of $2 \mathrm{~mL}$ were taken from each flask. The Simonsen (1974) technique was followed to clean all samples. Part of the material was mounted in Naphrax $^{\circledR}$ (Brunel Microscopes Ltd., Chippenham, Wilt-shire, UK) and examined with a light microscope (BX40, Olympus, Tokyo) equipped with an digital camera (OPT14000, Plustek, Taipei).

For scanning electron microscopy, cleaned specimens were dried onto a stub, and coated with platinum at $40 \mathrm{~mA}$ for 100 seconds using a sputter coater (Bal-tec SCD 050, Balzers, FL) Stubs were observed using a JEOL (JSM-6060, JEOL, Tokyo) scanning electronic microscope at an accelerating voltage of $15-20 \mathrm{kV}$ with a working distance of $10 \mathrm{~mm}$.

In two permanent slides for each sample, 400 valves were counted in order to calculate the relative frequency of each species (Schoeman, 1973). Species that achieve a higher count than the mean value were considered abundant.

The samples have been deposited in ICN and PEL herbaria of the Federal University of Rio Grande do Sul (UFRGS) and the Federal University of Pelotas (UFPel), respectivelly.

Beach classification follows Brown \& McLachan (1990) and diatom morphology terminology follows Hasle et al. (1983).

\section{Results And Discussion}

The distribution, general morphology and valve ultrastructure details of five Cymatosiraceae species are presented below:

Campylosira cymbelliformis (A. Schimdt) Grunow ex Van Heurck, Synopsis des Diatomées de Belgique, 158, 1885.

Synedra cymbelliformis A. Schmidt, Atlas der Diatomaceen-kunde. pl. 3, fig. 13. 1874.

Figures 1-2, 11-16

Observations: Cells cymbelliform, $16-28 \mu \mathrm{m}$ long and $4.5-5.5 \mu \mathrm{m}$ wide $(\mathrm{n}=20)$, were observed as isolated (Figure 1) or in short colonies from 2 to 4 frustules (Figure 2). It was observed 3 of the 4 valve types as described by Hasle et al. (1983): two internal valves both with linking spines in a Tshape (Figure 13), one with rimoportula and another valve without rimoportula (Figure 12), and an end valve with simple non-linking spines and no rimoportula (Figure 11). The interior valves can present a rimoportula (Figures 12,16) or not (Figure 12). The striae on the valve face are formed by round areolae $10-12$ in $10 \mu \mathrm{m}$ more or less organized in rows leaving a semi-circular central area on the dorsal (curved) side (Figure 11). Between the valve face and the mantle there is a row of simple non-linking spines on the end valves (Figure 11) or bifurcate linking spines (Figure 13) on the internal valva. One ocelluli formed by several porelli is present on each valve apex, turned towards the straight margin of the valve
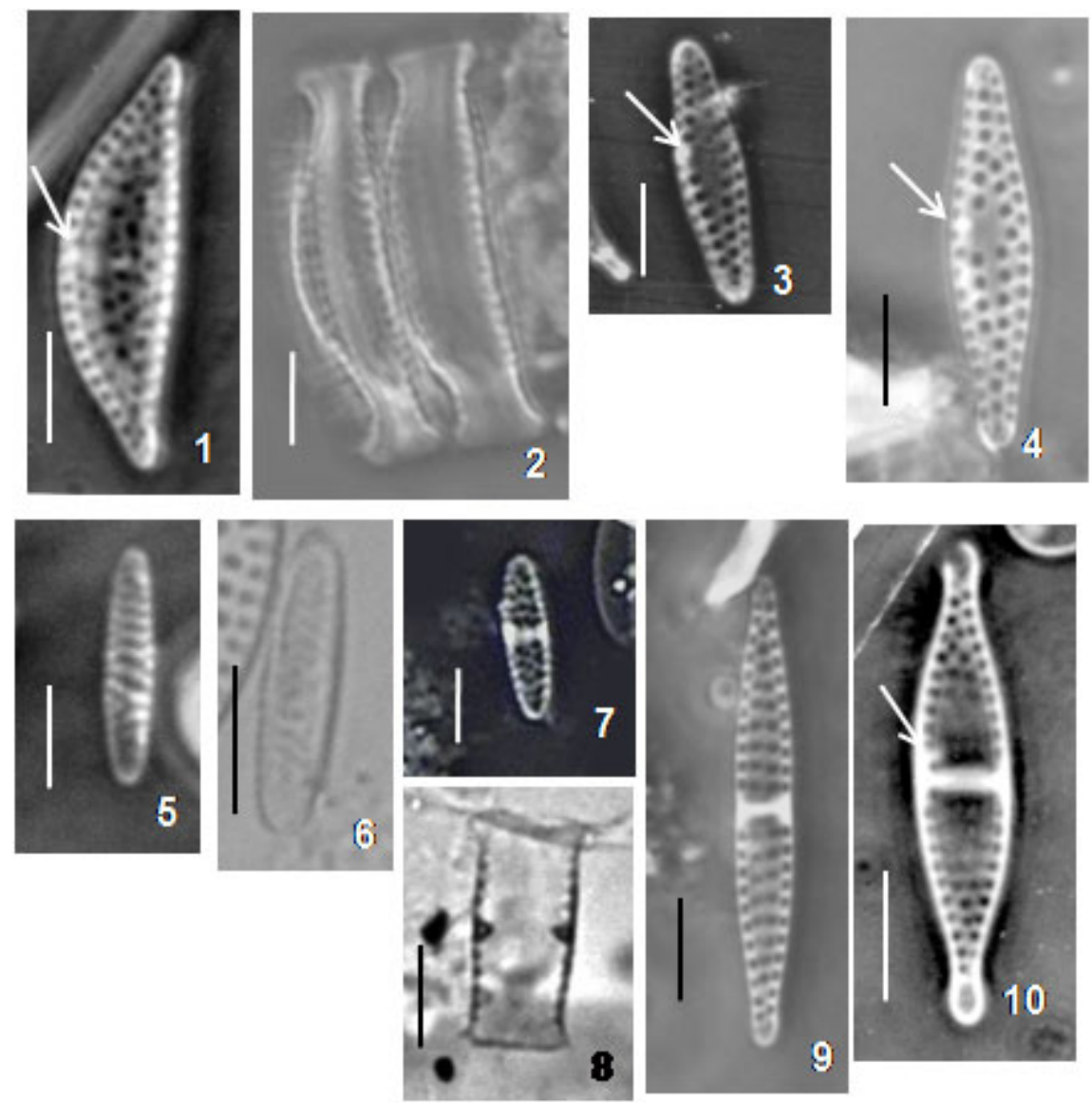

Figures 1-10. LM images. 1-2. Campylosira cymbelliformis. Fig. 1. Valva in valve view. Fig. 2. Chain with 2 frustules in girdle view. Figs 3-4. Cymatosira belgica. Valve views. Figs 5-6. Cymatosirella minutissima. Valve views. Figs 7-9. Plagiogrammopsis minima. Figs 7-8 Valve views. Fig. 9. Girdle view. Fig. 10. Plagiogrammopsis vanheurckii. Rimportula position is indicated by arrows. Scales: $5 \mu \mathrm{m}$. 

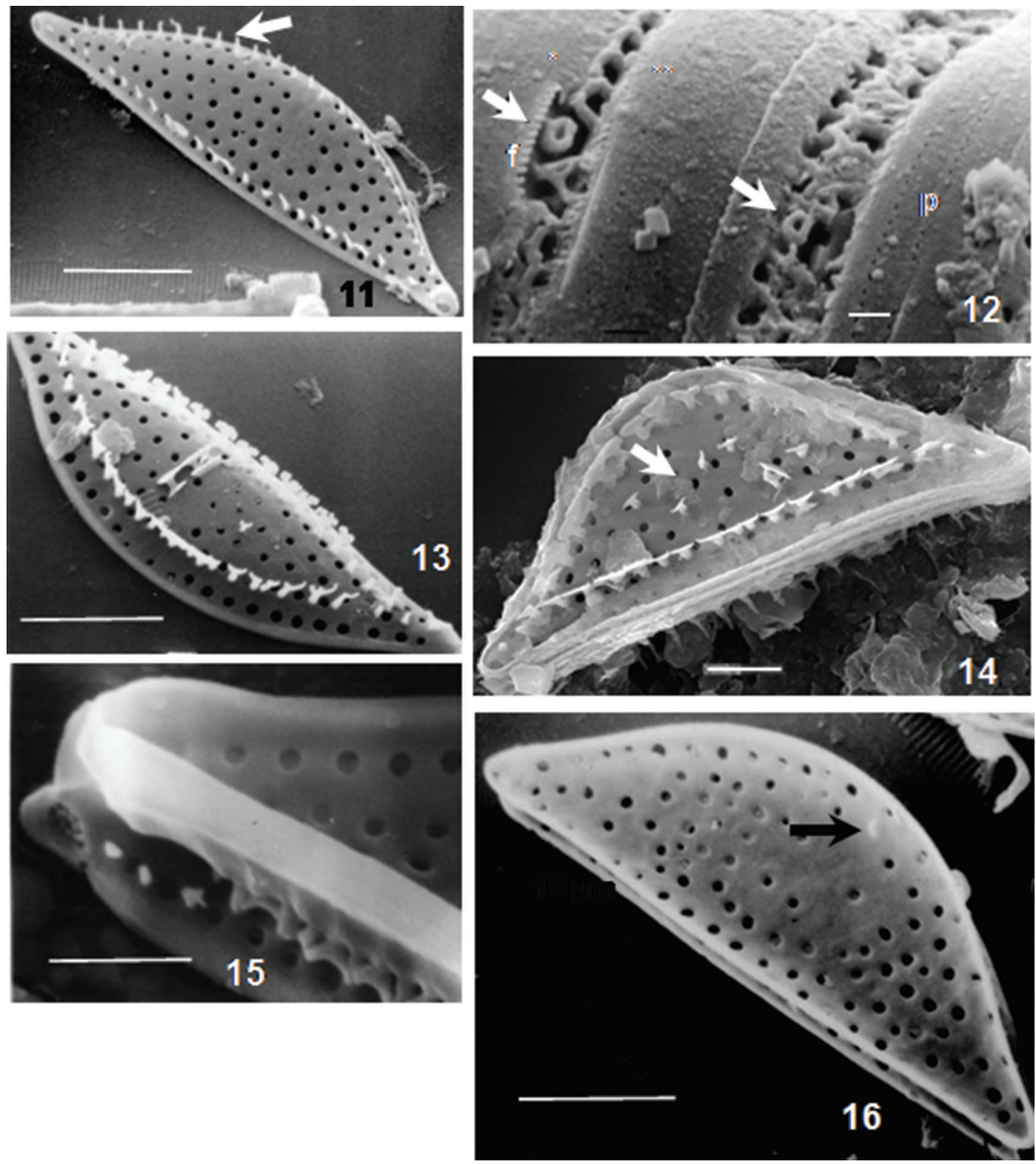

Figures 11-16. SEM images of Campylosira cymbelliformis. Fig. 11. External view of an end valve without rimportula and several simple non-linking spines (arrowed). Scale: $5 \mu \mathrm{m}$. Fig. 12. Colony with three frustules in girdle view showing valves with $(*)$ and without $(* *)$ rimportula. Note also bands ornamented by a row of poroids ' $p$ ' with margin finges ' $f$ ' and external rimportula aperture arrowed. Scale: $1 \mu \mathrm{m}$. Fig. 13. External view of a concave valve without rimoportula showing bifurcate linking spines between valve face and mantle. Scale: $5 \mu \mathrm{m}$. Fig. 14. Spore or resting valve? with bifurcate linking spines (arrowed) on the valve face. Scale: $2 \mu \mathrm{m}$. Fig. 15. Apex detail showing ocelluli in external view. Scale: $2 \mu \mathrm{m}$. Fig. 16. Internal view of an interior valve with rimportula indicated by an arrow. Scale: $5 \mu \mathrm{m}$.

(Figures 11, 15) and cigulum with bands ornamented by rows of porelli and fringes at its margin (Figure 12). The cell illustrated in Figure 14 may represent spores or a resting stage with bifurcated linking spines on the valve face.

Distribution in the studied area: Brazil, Santa Catarina State: Garopaba (2801’S; 48³7’W), sediment 13.V.2002 (PEL 23329); Itapirubá $\left(28^{\circ} 25^{\prime} \mathrm{S} ; 48^{\circ} 44^{\prime} \mathrm{W}\right)$, sediment 23.VI.2002 (PEL 22557); Mar Grosso $\left(28^{\circ} 28^{\prime} \mathrm{S} ; 48^{\circ} 46^{\prime} \mathrm{W}\right)$, sediment 08.XII.2001 (PEL 22564); Mariscal (2711'S; $\left.48^{\circ} 29^{\prime} \mathrm{W}\right)$, sediment 07.I.2001 (PEL 22574); Navegantes $\left(26^{\circ} 53^{\prime} \mathrm{S} ; 48^{\circ} 38^{\prime} \mathrm{W}\right)$ sediment 19.XII.2001 (PEL
23333); Praia do Iró ( $28^{\circ} 28^{\prime} \mathrm{S}$; $\left.48^{\circ} 45^{\prime} \mathrm{W}\right)$, sediment 08.XII.2001 (PEL 22848); Perequê (2709'S; 48³3’W), plankton 15.XII.1995 (ICN 91431), sediment 15.XII.1995 (ICN 91392), 22.I.1996 (ICN 91447). Rio Grande do Sul State: Cassino (32 ${ }^{\circ} 12^{\prime} \mathrm{S}$; $\left.52^{\circ} 10^{\prime} \mathrm{W}\right)$, plankton XII.2005, Tramandaí $\left(30^{\circ} 15^{\prime} \mathrm{S} ; 50^{\circ} 30^{\prime} \mathrm{W}\right)$, plankton 29. XI.1995 (ICN 91430), 22.I.1996 sediment (ICN 91509).

Dimension and morphological data are in agreement with Hustedt (1939) and Hasle et al. (1983).

All beaches listed above can be classified as dissipative, with the exception of Perequê beach, which is a beach located in a bay. 

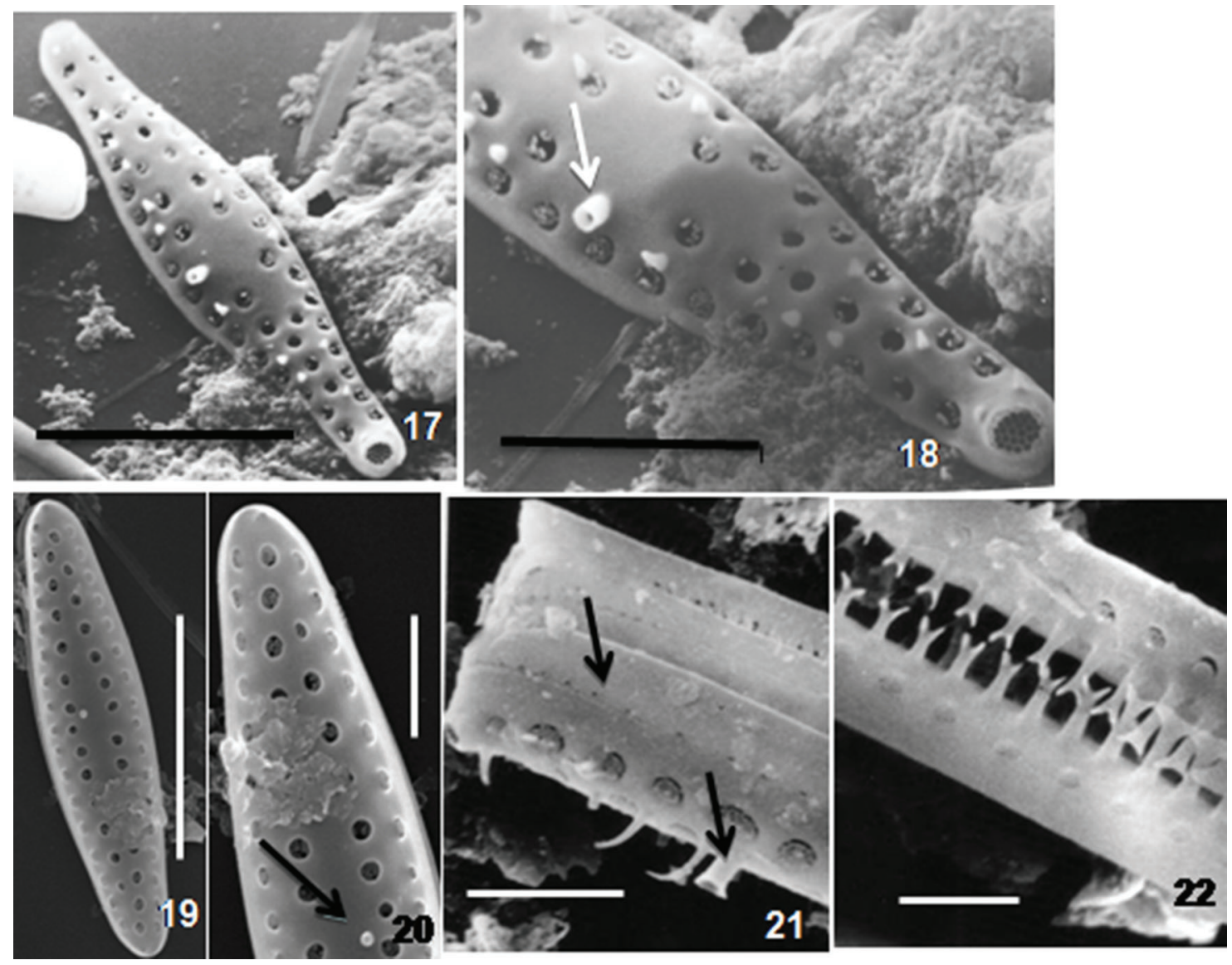

Figures 17-22. Cymatosira belgica. Fig. 17. view of an external valve with linear lanceolate outlline. Scale: $5 \mu$ m. Fig. 18. Detail of Fig. 17 showing the rimportula (arrowed) and simple spines. Scale: $2.5 \mu \mathrm{m}$. Fig. 19. Internal view of a valve with elliptical lanceolate outlline. Scale: $5 \mu \mathrm{m}$. Fig. 20. Detail of fig. 19 showing rimportula aperture internally (arrowed). Scale: $2 \mu \mathrm{m}$. Fig. 21. Part of a valve in external view showing bands ornamented by one row of poroids, external tube of rimportula and areolae occluded by cribrum and simple spines. Scale: $2 \mu \mathrm{m}$. Fig. 22 . Part of two valves in girdle view showing bifurcate linking spines. Scale: $2 \mu \mathrm{m}$.

Cymatosira belgica Grunow In Van Heurck, Synopsis des Diatomées de Belgique, Pr. 45, figs. 38-41, 1881.

Figures 3-4, 17-22

Observations: According to Hasle et al. (1983) this taxon forms a colony with distinct morphological cells inside and outside of the colony with at least three types of valves. During this study, external valves with simple non-linking spines (Figures 17, 21) and internal valves with bifurcate linking spines were observed (Figure 22). The valves are elliptical to linear lanceolate in shape, $15-18 \mu \mathrm{m}$ long and $3.5-4.5 \mu \mathrm{m}$ wide $(\mathrm{n}=25)$ (Figures 17,19$)$. Round areolae $(10-14$ in $10 \mu \mathrm{m})$ are occluded by external cribrum (Figure 17) and organized in rows parallel to an apical axis (Figure 19). One central rimoportula is present inside the areolae row located on the valve face in all cells observed (Figures 18-20). The cingulum is composed of bands ornamented by rows of poroids (Figure 21).

Distribution in the studied area: Brazil, Santa Catarina State: Gamboa (275' S; 48 37'W), sediment 13.V.2002 (PEL 22575); Mariscal (27¹1'S; $48^{\circ} 29^{\prime} \mathrm{W}$ ), sediment 22.I.1996 (ICN 91479, ICN 91482, ICN 91483, ICN 91484), 07.I.2002 (PEL 22574, PEL 22569); Quatro Ilhas (2709'S; $\left.48^{\circ} 29^{\prime} \mathrm{W}\right)$, sediment 22.I.1996 (ICN 91468, ICN 91469, ICN 91470), 07.I.2002 (PEL 23336); Perequê (2709'S; 48³3'W), sediment 15.XII.1995
(ICN 91447); Zimbros (27 $\left.12^{\prime} \mathrm{S} ; 48^{\circ} 29^{\prime} \mathrm{W}\right)$, sediment 22.I.1996 (ICN 91485), 07.I.2002 (PEL 22622, PEL 23259); Rio Grande do Sul State: Cassino (32 ${ }^{\circ} 12^{\prime} \mathrm{S}$; $\left.52^{\circ} 10^{\prime} \mathrm{W}\right)$, plankton III.2001, X.2005.

Dimensions and morphology are in agreement with Hasle et al. (1980). In our samples C. belgica was found in a wide range of sandy beaches (from dissipative sandy beaches [open] to bays [closed]) and in plankton. This distribution is in agreement with that found in the literature and cited in the introduction. Silva et al. 2010 found one valve of it in sediments from the Lagoa dos

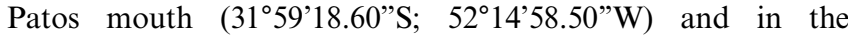
Westerschelde estuary (The Netherlands) it occurs in silty sediments (low dynamic environments) and plankton samples (Muylaert \& Sabbe, 1999).

Cymatosirella minutissima (Sabbe \& Muylaert) Dabek, Witkowski \& Sabbe, Phytotaxa, 121: 50. 2013.

Cymatosira minutissima Sabbe \& Muylaert, Vie Milieu, 60: 246, figures 17-20, 28,31. 2010.

Figures 5-6, 23-28

Observations: The identification of this tiny taxon depends on Electronic Microscope observations (Figures 5, 6). The valves are round to elliptical lanceolate in shape, $3.0-9 \mu \mathrm{m}$ long and $1.5-3 \mu \mathrm{m}$ wide $(\mathrm{n}=10)$. The areolae are arranged irregularly or organized in lines (Figure 27) occluded by 

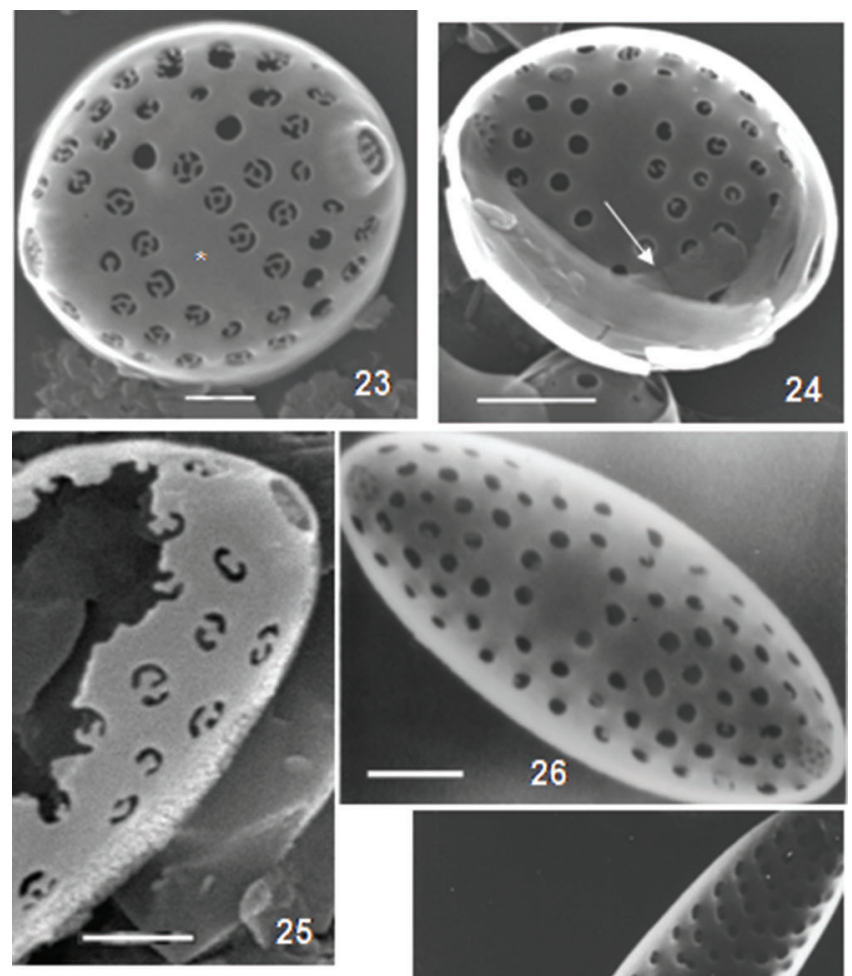

$\longrightarrow$

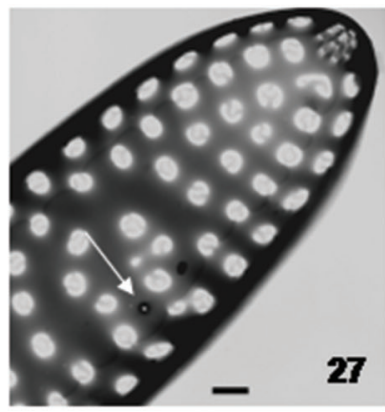

27
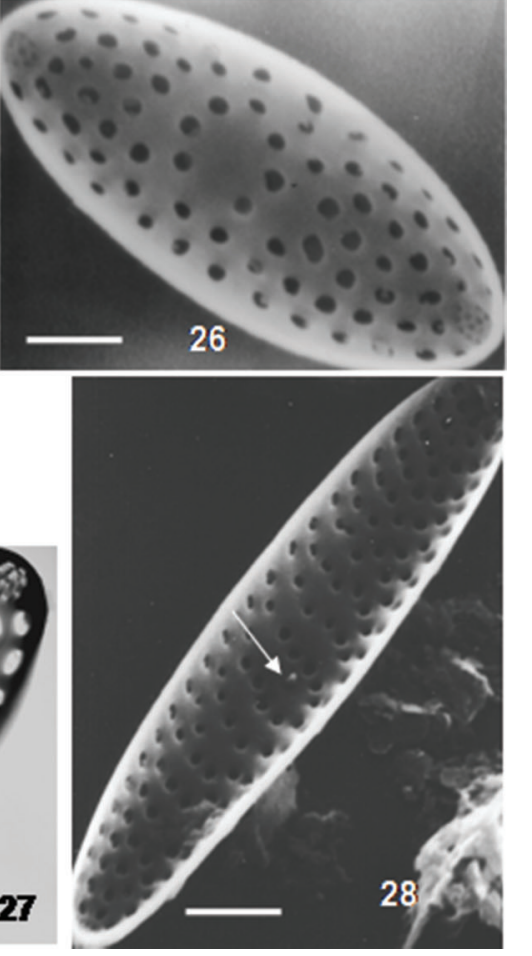

Figures 23-28. Cymatosirella minutissima. Figs 23-26, 28. SEM images. Fig. 27. TEM image. Fig. 23. External view of a valve with round outline. Note the presence of a central area $(*)$. Scale: $0.5 \mu \mathrm{m}$. Fig. 24. Internal view of a valve with round outline, bands are indicated. Scale: $1 \mu \mathrm{m}$. Fig. 25. External view of part of a valve with elliptical outline. Scale: $0.5 \mu \mathrm{m}$. Fig. 26. Internal view of a valve with elliptical outline. Scale: $1 \mu \mathrm{m}$. Fig. 27. Part of a valve showing the presence of central circular area, rimportula (indicated) and ocelluli with 10 porelli. Scale: $200 \mathrm{~nm}$. Fig. 28. Part of a valve in internal view showing the presence of central circular area and rimportula (indicated).

external cribra, $12-15$ in $10 \mu \mathrm{m}$ (Figures 23, 25). The valvar face is flat (Figures 23, 24, 26, 28). The central area is circular with one rimoportula sometimes present (Figures 27-28). Two ocelluli with 10 porelli ( 2 centrally located), open slightly laterally on the valve (Figure 23). The marginal spines were not observed and cingulum composed of several bands were not ornamented (Figure 24).

Distribution in the studied area: Brazil, Santa Catarina State: Araçá $\left(27^{\circ} 08^{\prime} \mathrm{S} ; 48^{\circ} 31^{\prime} \mathrm{W}\right)$, sediment 05.I.2002 (PEL 22618); Mariscal (27 $11^{\circ} \mathrm{S}$; $\left.48^{\circ} 29^{\prime} \mathrm{W}\right)$, sediment 07.I.2002 (PEL 22574); Zimbros $\left(27^{\circ} 12^{\prime} \mathrm{S} ; 48^{\circ} 29^{\prime} \mathrm{W}\right)$, sediment 15. XII.1995 (ICN 91415, ICN 91416, ICN 91417).

Dimensions and morphology are in agreement with Dabek et al. (2013). During this study it was possible to show the presence of the rimoportula not observed by Sabbe et al. 2010. Cymatosirella
Dabek et al. was included in the Extubocelluloideae where rimoportula are occasionally observed and our findings are in agreement with the occasional occurrence of rimoportula in this family.

Among the species studied, it seems to present a more restricted distribution, but it may be related to its small size.

Our distribution data is not fully in agreement with Sabbe et al. 2010. The authors found C. minutissima on sandy areas (more dynamic) and we have it on beaches under distinct hydrodynamics such as Mariscal (an open, dissipative sandy beach) and Zimbros (bay).

Plagiogrammopsis minima (Salah) Sabbe \& Witkowski, Vie Milieu, 60: 246, figures 7-10, 32-35, 43-44. 2010.

Plagiogramma minimum Salah, Hydrobiologia, 7: 91, Pl.1, fig. 15. 1955.

Figures 7 - 9, $29-36$

Observations: The valves are lanceolate with rounded apices, $9.0-13.0 \mu \mathrm{m}$ long and $1.5-2.5 \mu \mathrm{m}$ wide $(\mathrm{n}=22)($ Figures 7,9$)$. The valves present a slightly twisted outline with ocelluli opening in opposite directions (Figure 30). At the center, the valve presents a fascia outside and a pseudoseptum inside (Figures 29, $30,32,33)$. Next to the pseudoseptum, at the valve edge, there is one rimoportula observable outside as a simple aperture (Figures 29, 31). The striae are composed of two areolae, one on the valve face and another on the mantle. Areolae are round (12-20 in $10 \mu \mathrm{m})$ and occluded by external cribrum that is, sometimes, covered by spinules (Figures 35 and 36). Granule-like spines can be observed scattered on the valve face (Figures 30, 31) and copulae present one row of poroids (Figure 36). Frustules are connected by short (Figure 35) simple spines although long simple spines are observable on valve face sometimes (Figure 36).

Distribuition in the studied area: Brazil, Santa Catarina

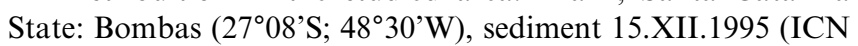
91403, ICN 91404); Gamboa (2757’'S; 48³7’W), sediment 13.V.2002 (PEL 22575, PEL 23329); Jeremias (2655'S; 48³8'W), sediment 02.XII.2001 (PEL 23683); Guarda do Embaú (275'; ; 48 58'W), sediment 08.XII.2001 (PEL 22613); Mariscal (27¹1'S; 48²9'W), sediment 22.I.1996 (PEL 91483, PEL 91484, PEL 91485); Penha ( $\left(26^{\circ} 47^{\prime} \mathrm{S} ; 48^{\circ} 36^{\prime} \mathrm{W}\right)$, sediment 19.XII.2001 (PEL 22832, PEL 23348); Pinheira (27 $84^{\prime} \mathrm{S} ; 48^{\circ}$ 58'W), sediment 08.XII.2001 (PEL 23257); Quatro Ilhas $\left(27^{\circ}\right.$ 09'S; 48²9'W), sediment 07.I.2002 (PEL 23269, PEL 22838, PEL 23336), 22.I.1996 (PEL 91468, PEL 91469); São Miguel (2649'S; 48³6'W), sediment 19.XII.2001 (PEL 22550); Siriú (27 $\left.58^{\prime} \mathrm{S} ; 4^{\circ} 37^{\prime} \mathrm{W}\right)$, sediment 22.VI.2002 (PEL 22568, PEL 22590); Zimbros $\left(27^{\circ} 12^{\prime} \mathrm{S} ; 48^{\circ} 29^{\prime} \mathrm{W}\right)$, sediment 22.I.1996 (ICN 91485).

Dimensions and morphology are in agreement with Sabbe et al. (2010), although the number of areolae in $10 \mu \mathrm{m}$ is somewhat higher. In the original description the rimoportula is located next to striae while in the Brazilian material is located always next to the pseudoseptum. Sabbe et al. 2010 found it in abundance in summer time as we have observed as well. They also refer to it as a species from sandy sediments (more dynamic areas), on the other hand we observed it on all types of sandy beaches (dissipative, intermediate and reflective) and abundant in low dynamic (Zimbros on January 1996) and dynamic beaches (Quatro Ihas on January 2002).

The presence of a row of poroids on copulae of $P$. minima was not observed by Sabbe et al. (2010) and this finding is in agreement with Cymatosiraceae diagnosis. 

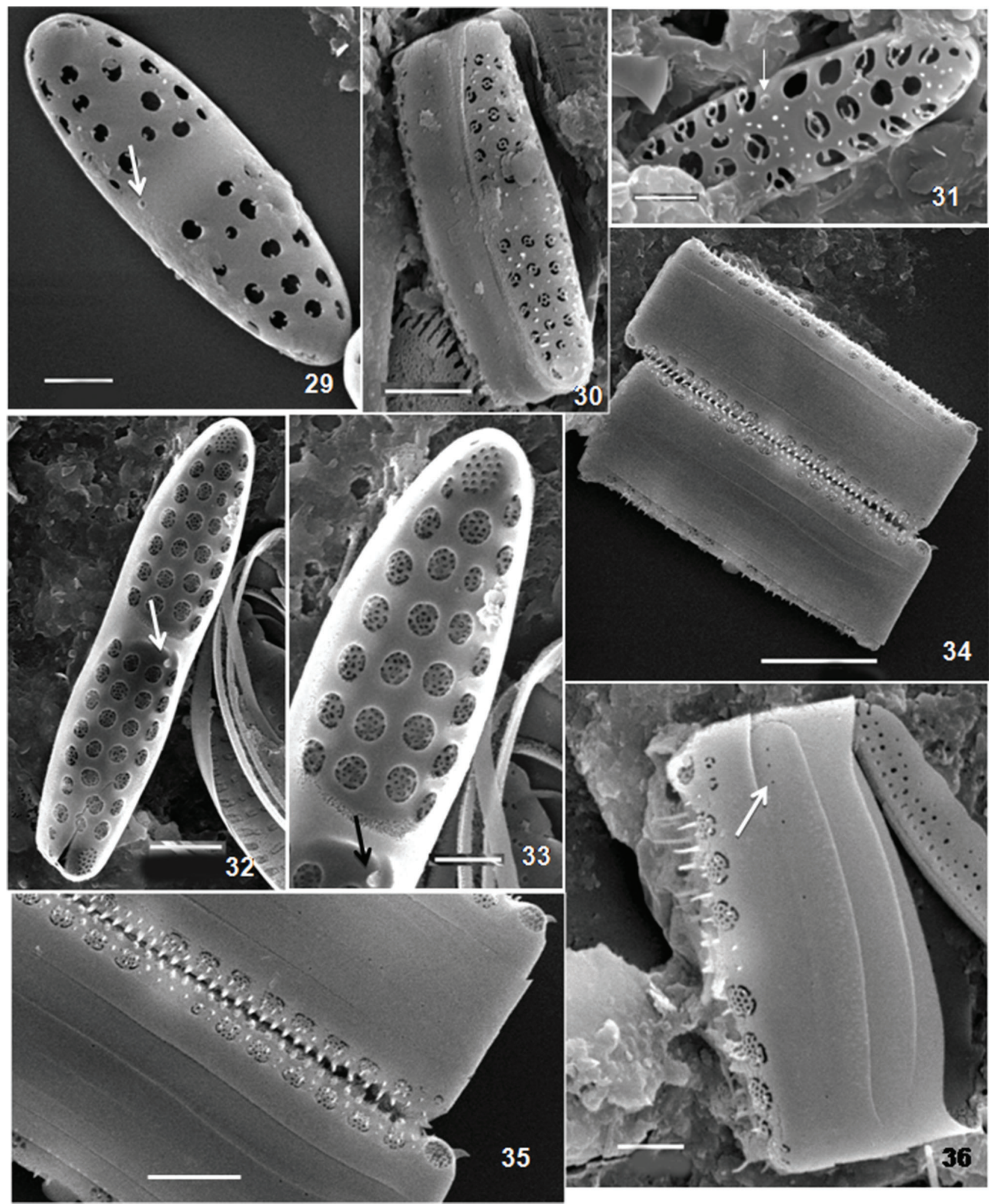

Figures 29-36. Plagiogrammopsis minima. Fig. 29. External view of a valve with areolae eroded and external aperture of the rimoportula indicated. Scale: $1 \mu \mathrm{m}$. Fig. 30. External view of a frustule showing valve face with several eroded spines. Scale: $2 \mu \mathrm{m}$. Fig. 31 . Part of a valve in external view showing partialy eroded areolae occlusion, spines and rimoportula aperture arrowed. Scale: $1 \mu \mathrm{m}$. Fig. 32. General view of a valve in internal view. Internal rimportula aperture is arrowed. Scale: $1 \mu \mathrm{m}$. Fig. 33. Detail of fig. 32, note cribrum occlusion located outside of the areolae and internal rimoportula aperture arrowed next to the pseudoseptum. Scale: $1 \mu \mathrm{m}$. Fig. 34. External general view of two frustules. Scale: $5 \mu \mathrm{m}$. Fig. 35 . Detail of fig. 34. showing in detail a row of short spines between valve face and mantle. Scale: $2 \mu \mathrm{m}$. Fig. 36. External view of valve in girdle view showing open bands ornamented by a row of poroids and spinules on the cribra. Scale: $1 \mu \mathrm{m}$. 
Plagiogrammopsis vanheurckii (Grun.) Hasle, von Stosch \& Syvertsen, Bacillaria, 6: 31, figures. 104-131. 1983.

Plagiogramma vanheurckii Grunow in Van Heurck, Synopsis des Diatomées de Belgique. pl. 36. fig. 4. 1881.

Figure 10

Observations: The cell is lanceolated in shape, $18 \mu \mathrm{m}$ long and $3.5 \mu \mathrm{m}$ wide $(\mathrm{n}=1)$, with long produced apices. Small round areolae are observed scattered or forming transapical rows on the valve face. At the middle of the valve there is a pseudoseptum and next to it and the valve margin one rimoportula is present (Figure 10). Only one isolated valve was observed.

Distribution in the studied area: Brazil, Santa Catarina State: Quatro Ilhas (2709'S; 48²9’W), sediment 22.I.1996 (ICN 91467).

Morphological and dimension data are in agreement with Hasle et al. (1983). This taxon was registered to the marine beaches of Cabeçudas, Piçarras, Itajubá e Barra Velha by Valente-Moreira \& Moreira-Filho (1978) and Ilha de Florianópolis por Corte-Real \& Aguiar (1971). It seems nowadays a rarer species than some years ago, although the beaches cited above have not been included in this study.

\section{Final Discussion}

Cymatosiraceae species were found attached to sand grains and plankton samples of sandy beaches of the South of Brazil. The few recordings to the Brazilian coast may be related to the diminute size of these diatoms.

Among the species studied, two are recorded in abundance on sediments, Cymatosira belgica at Mariscal and Plagiogramma minina at Quatro Ilhas and Zimbros, both in January 1996 (Table 1).

Regarding the occurrence of Cymatosiraceae species in plankton samples, C. cymbelliformis was registered to Tramandaí, Cassino, and Perequê and Cymatoisra belgica to Cassino. These characteristic benthic species may be found in plankton, although never in abundance.

Based on beaches studied in this paper, Campylosira cymbelliformis is more likely to occur in shallow open coastal (dissipative) beaches such as Navegantes, Itapirubá, Mariscal in Santa Catarina State, and Tramandaí and Cassino, and also in Praia Azul according to Garcia-Baptista (1993), in Rio Grande do Sul State (Table 1).

Cymatosira belgica was abundant at an open sandy beach such as Mariscal and can be considered a common diatom in the Santa Catarina littoral but it is very rare in the Rio Grande do Sul littoral. Garcia-Baptista (1993) observed over a 128 sand samples from Praia Azul and has never observed it. It is herein for the first time recorded for the Rio Grande do Sul littoral at Cassino beach. Although Silva et al. (2010) has cited it to Lagoa dos Patos estuary, its ocurrence in this area maybe is related to the proximity with the international port of Rio Grande.

The distribution of Cymatosirella minutissima and Plagiogrammopsis minima are amplified to South America, before they were restricted to Europe.

The ecological data for Plagiogrammopsis minina (the widest spread diatom in this study) and Cymatosirella minutissima are not fully in agreement with Sabbe et al. 2010 that found both species on sandy (more dynamic) areas. In Brazil, on the other hand they were observed in Mariscal (open) and Zimbros (closed) beaches.
Regarding morphological diagnostic features new data were added to some taxa as the presence of rimoportula on C. minutissima and one row of poroids on copulae of P. minima.

This study shows higher diversity of Cymatosiraceae present on Brazilian beaches than previously, especially on the beaches located along Santa Catarina State, area where there are diverse types of beaches. These distinct pattern distributions relight the necessity of more studies on the marine flora of Brazil.

\section{Acknowledgments}

I am thankful to Dr. Graziela Miot da Silva for showing me beaches such as Garopaba, Itapirubá, Siriú and Gamboa and for her friendship and company during field trips during 2002. I wish to thank Karina Marckmann and Leandro Menezes Baum (Electron Microscopy Center of UFRGS, Porto Alegre) for their help with the SEM.

\section{References}

BROWN, A.C. \& McLACHLAN, A. 1990. Ecology of Sandy Shores. Amsterdam, The Netherlands, Elsevier. 328pp.

BUSELATO-TONIOLLI, T.C. 1986. Diatomoflórula (Bacillariophyceae) associada à Hypnea musciformis (Wulfen) Lamouroux (Rhodophyceae) do litoral de Torres, Rio Grande do Sul, Brasil. Iheringia, Série Botânica, 35: 65-126.

CÔRTE-REAL, M. \& AGUIAR, L.W. 1971. Diatomáceas da Ilha de Santa Catarina e regiões vizinhas. I. Baía Norte e Palhoça. Iheringia, Série Botânica 15: 53-73.

DABEK, P., SABBE, K., WITKOWSKI, A., ARCHIBALD, C., KURZYDLOWSKI, K.J. \& ZGLOBICKA, I. 2013. Cymatosirella Dạbek, Witkowski \& Sabbe gen. nov. a new marine benthic diatom genus (Bacillariophyta) belonging to the family Cymatosiraceae. Phytotaxa 121 (1): 42-56. http://dx.doi.org/10.11646/phytotaxa.121.1.2

GARCIA-BAPTISTA, M. 1993. Psammic algae from Praia Azul, Brazil. Berlin, J. Cramer. 167 pp. and 279 figures. (Bibliotheca Phycologica, 94).

GARCIA, M. 2013. Extubocellulus brasiliensis (Bacillariophyceae), a new species from southern Brazilian marine sandy beaches. Diatom 29:20-23. http://dx.doi.org/10.11464/diatom.29.20

HASLE, G.R., von STOSCH, H.A. \& SYVERTSEN, E.E. 1983. Cymatosiraceae, a new diatom family. Bacillaria 6: 1-156.

HASSAN, G.S., ESPINOSA, M.A. \& ISLA, F.I. 2009. Diatom-based inference model for paleosalinity reconstructions in estuaries along the northeastern coast of Argentina. Palaeogeography, Palaeoclimatology, Palaeoecology 275: 77-91. http://dx.doi.org/10.1016/ j.palaeo.2009.02.020

HUSTEDT, F. 1939. Die Diatomeenflora des Küstengebietes der Nordsee vom Dollart bis zur Elbemündung. I. Die Diatomeenflora in den Sedimenten der unteren Ems sowie auf den Watten in der Leybucht, des Memmert und bei der Insel Juist. Adhandlungen des Naturwissenschaftlichen Verein zu Bremen 31: 571-677.

MANOYLOV, K.M. \& DOMINY Jr., J.N. 2013. Changes in Epipelic Diatom Diversity from the Savannah River Estuary. Journal of Environmental Protection 4: 172-179. http://dx.doi.org/10.4236/ jep. 2013.42020

MUYLAERT, K. \& SABBE, K. 1999. Spring phytoplankton assemblages in and around the maximum turbidity zone of the estuaries of the Elbe (Germany), the Schelde (Belgium/The Netherlands) and the Gironde (France). Journal of Marine System 22: 133-149. http://dx.doi.org/10.1016/S0924-7963(99)00037-8

PROCOPIAK, L.K., FERNANDES, L.F. \& MOREIRA FILHO, H. 2006. Diatomáceas (Bacillariophyta) marinhas e estuarinas do Paraná, Sul do Brasil: lista de espécies com ênfase em 
espécies nocivas. Biota Neotropica, 6: http://www.biotaneotropicaorg.br/v6n3/pt/abstract?inventory + bn02306032006 ISSN 1676-0603.

ROSA, Z.M. 1982. Diatomáceas marinhas e estuarinas de Tramandaí, Rio Grande do Sul, Brasil. Iheringia, Série Botânica, 29: 49-145.

SABBE, K., VANELSLANDER, B., RIBEIRO, L., WITKOWSKI, A., MUYLAERT, K. \& VYVERMAN, W. 2010. A new genus, Pierrecomperia gen. nov., a new species and two new combinations in the marine diatom family Cymatosiraceae. Vie et milieu - life and environment 60: 243-256.
SCHOEMAN, F.R. 1973. A systematical and ecological study of the diatom flora of Lesotho with special reference to the water quality. Pretoria, V\&R Printers. 365 pp.

SILVA, J.G. da, TORGAN, L.C. \& CARDOSO, L.S. 2010. Diatomáceas (Bacillariophyceae) em marismas no Sul do Brasil. Acta Botanica Brasilica 24: 935-947. http://dx.doi.org/10.1590/S010233062010000400008

SIMONSEN, R. 1974. The diatom plankton of the Indian Ocean Expedition of R/V "Meteor". "Meteor" Forsch.-Ergebnisse 19 (D): $1-107$. 